\title{
Pelargonium sidoides extract EPs 7630: a review of its clinical efficacy and safety for treating acute respiratory tract infections in children
}

This article was published in the following Dove Press journal: International Journal of General Medicine

\author{
Domenico Careddu' \\ Andrea Pettenazzo ${ }^{2}$ \\ 'Pediatrics, Italian Health Service, \\ Cameri, Italy; ${ }^{2}$ Department of \\ Women's and Children's Health, \\ University Hospital of Padua, \\ Padova, Italy
}

Correspondence: Domenico Careddu Strada Privata XXV Aprile 4, 28062

Cameri, NO, Italy

Tel +393473886217

Email dom.careddu@alice.it
Background: In numerous randomized controlled trials (RCTs) and systematic reviews such as those published by the Cochrane Collaboration, Pelargonium sidoides extract $\operatorname{EPs}^{\circledR} 7630$ was shown to be effective in acute respiratory tract infections (aRTI) in all investigated age-groups. This narrative review focuses on recently published results from RCTs investigating the clinical efficacy and safety of EPs 7630 in children and adolescents with different manifestations of aRTI, in order to present a broader overview and to provide an update on the state of knowledge regarding the use of EPs 7630 in this age-group.

Methods: The Cochrane review on $P$. sidoides extract for aRTI published by the Cochrane Collaboration was searched for cited RCTs with EPs 7630 in children and adolescents suffering from aRTI. A PubMed and SCOPUS literature search was performed for publications issued before June 13, 2017 (search terms: children, Pelargonium sidoides, EPs 7630, respiratory). Reference lists of publications found were searched for relevant citations.

Results: Eight RCTs investigating the application of EPs 7630 in acute bronchitis, acute tonsillopharyngitis, and aRTI in the context of chronic preconditions were identified. Results showed a statistically significant improvement of aRTI symptom severity for EPs 7630 as compared to controls. The investigation of EPs 7630 in asthmatic children and adolescents with aRTI demonstrated a significant symptom-alleviating effect and a possibly associated reduction of asthma attacks. In immunocompromised children with acute upper RTI, an alleviating effect of EPs 7630 was shown. All RCTs reviewed reported good safety and tolerability of EPs 7630 . Conclusion: The $P$. sidoides extract EPs 7630 is effective and safe for those of pediatric age and may be regarded as an alternative option for the management of aRTI.

Keywords: Pelargonium sidoides, EPs 7630, children, acute respiratory tract infections, acute bronchitis, asthma

\section{Introduction}

Pelargonium sidoides, a traditional medicinal plant native to South Africa, shares the same genus (Pelargonium) with the common ornamental geraniums. ${ }^{1}$ The roots of $P$. sidoides have centuries-long been used as herbal remedies for respiratory and gastrointestinal infections by the local populations..$^{2-4}$ Only 120 years ago, it was described by the Englishman Charles Henry Stevens, who praised the root as a new remedy for tuberculosis. ${ }^{5}$ Identification of numerous compounds of $P$. sidoides roots, such as prodelphinidins, methoxycoumarin, and proanthocyanidins, ${ }^{6}$ led to the production of an ethanolic extract known as EPs $^{\circledR} 7630$ (the active ingredient of the product Umckaloabo ${ }^{\circledR}$, ISO-Arzneimittel, Ettlingen, Germany). Today, the liquid herbal drug preparation EPs 
7630 from the roots of $P$. sidoides (1:8-10), extraction solvent: ethanol $11 \%(\mathrm{w} / \mathrm{w})$, has been approved for the treatment of acute respiratory tract infections (aRTI) in several countries in Europe, Asia, Australia, and Central and South America.

Documented pharmacological activities of EPs 7630 include antiviral and antibacterial action as well as immunemodulatory capabilities..$^{7-17}$ Several in vitro studies conducted with EPs 7630 showed an inhibitory effect (growth inhibition) against several bacterial strains (Klebsiella pneumoniae, Escherichia coli, Pseudomonas aeruginosa, Proteus mirabilis, and Staphylococcus aureus, especially multi-resistant strains). ${ }^{9}$ This effect is brought about by an immune modulation mechanism mediated by the activation of macrophages (with the involvement of cytokine interferon-gamma) and the consequent increase in the production of nitric oxide. ${ }^{10,11}$ The activated macrophages produce, in turn, different cytokines, such as interleukin (IL)-1, IL-2, and tumor necrosis factor-alpha. ${ }^{11} P$. sidoides also modulates the production of secretory immunoglobulin A in saliva, IL-15 in the serum and nasal mucosa, and IL-6 in the serum. ${ }^{3}$ Biological and pharmacological properties of EPs 7630 are summarized in Figure 1.

The antiviral effect of EPs 7630 is reported to be linked to the production of interferons, ${ }^{9}$ although a recent study ${ }^{12}$ highlighted a direct antiviral effect on several viruses (influenza, parainfluenza, respiratory syncytial viruses, rhino viruses, coxsackie, and coronaviruses).

The recently published studies by Theisen and Muller ${ }^{13}$ and Brown ${ }^{14}$ demonstrated an infection-inhibiting effect of EPs 7630. The mode of action is described by Conrad et al ${ }^{15}$ and Janecki et al $^{16}$ as an exertion of a specific antagonistic effect against the adhesion proteins on the bacterial surface (group A Streptococcus), thus preventing adhesion to epithelial cells and subsequent penetration of them. This specific activity appears to be mediated by the proanthocyanidins, which are contained in the extract. Another possible

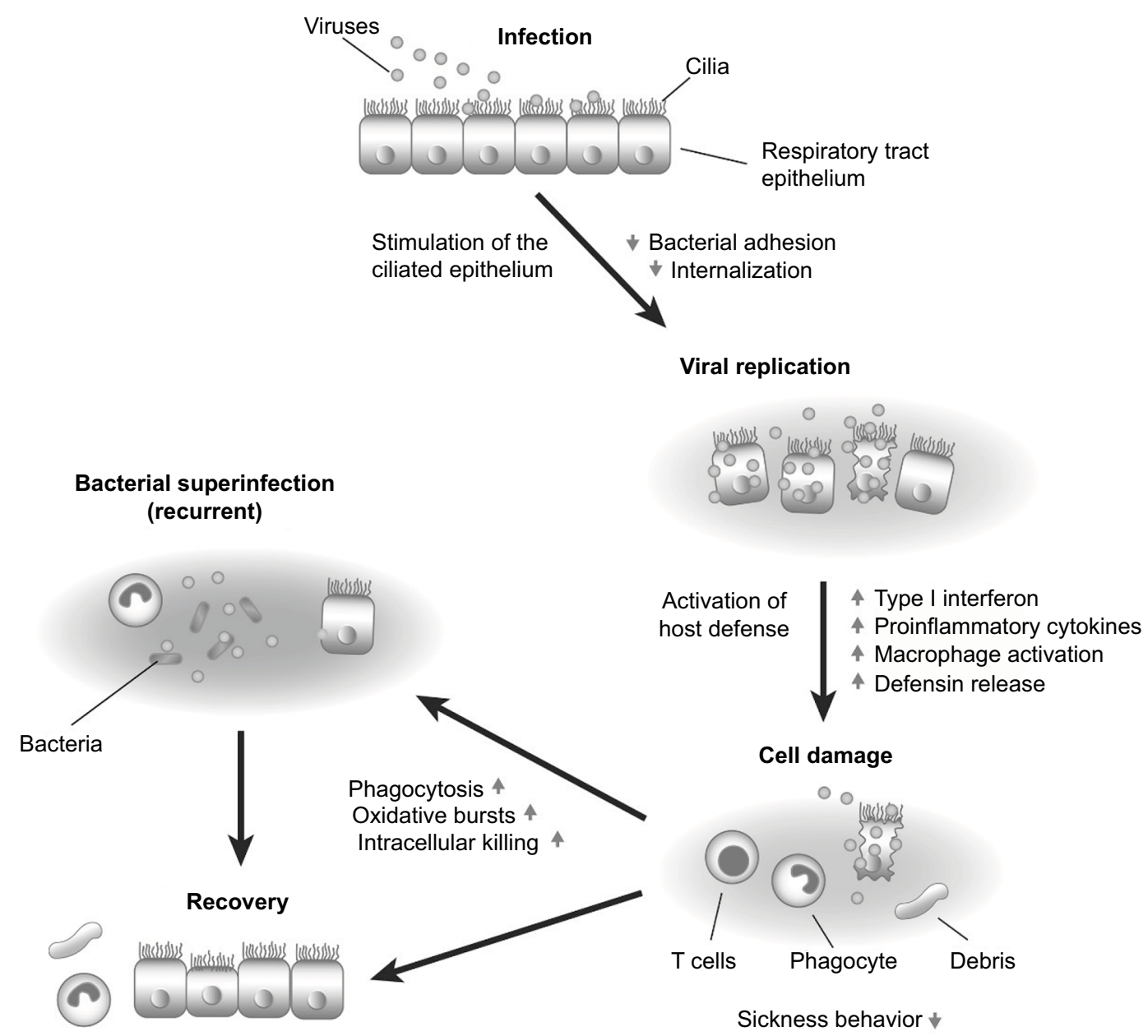

Figure I Mechanism of action of $\mathrm{EPs}^{\circledR} 7630$.

Note: Adapted by permission from Springer Nature: Wien Med Wochenschr. Pelargonium sidoides-Extrakt (EPs $\left.{ }^{\circledR} 7630\right)$ : Zulassung bestätigt Wirksamkeit und Verträglichkeit [Pelargonium sidoides-extract $\left(\mathrm{EPs}^{\circledR}{ }^{\circledR} 7630\right)$ : registration confirms efficacy and safety]. Conrad A, Kolodziej H, Schulz V. Copyright 2007. ${ }^{18}$ 
mechanism of protection could be linked to an increase in the ciliary motility of the respiratory epithelium, as shown by preliminary in vitro studies that assessed the effect of EPs 7630 on cultured human respiratory mucosa cells. ${ }^{17}$

Between 1994 and 2009, 304 million daily doses of EPs 7630 ( $4.5 \mathrm{~mL}$ of solution or 3 tablets) were sold. ${ }^{14}$ In addition to the decade-long presence on the international market, the efficacy and safety of EPs 7630 in aRTI have till today been widely demonstrated in several placebo-controlled clinical trials and open clinical studies ${ }^{19}$ as well as by postmarketing surveillance data. ${ }^{20-22}$

aRTI are very common in children, and EPs 7630 was shown to be not only an effective but also a safe treatment for these ailments, also for children of preschool age. ${ }^{23}$ Moreover, based on the available data, the European Respiratory Society has acknowledged $P$. sidoides root extract as a natural remedy available for the treatment of the symptoms of acute bronchitis $(\mathrm{AB}) .^{24}$

In 2013, a review on $P$. sidoides extract for aRTI was published by the Cochrane Collaboration. ${ }^{25}$ Among the placebocontrolled randomized clinical trials that were available for full evaluation, 4 were conducted in children and adolescents. The aim of the current review is to have a closer look at these trials as well as on further randomized controlled trials (RCTs) published afterward or not included into the Cochrane review in order to provide a current overview of published clinical trials investigating the efficacy of EPs 7630 in children and adolescents suffering from different manifestations of aRTI.

\section{Materials and methods}

For this narrative review, both open and double-blind RCTs investigating the efficacy of EPs 7630 in children and adolescents suffering from aRTI were eligible. Control groups in eligible trials were allowed to be randomized to either placebo or, in open-label trials, to nonmedication. Clinical trials available for full evaluation were identified from the Cochrane Review authored by Timmer et al. ${ }^{25}$ In addition, a literature search was performed in the scientific databases PubMed and SCOPUS in order to identify additional eligible trials published afterward or formerly not included in the current Cochrane review. Search terms applied were children, EPs 7630, Pelargonium sidoides, respiratory. Publications found were also searched for relevant citations in the respective reference lists.

A total of 8 RCTs were identified and included into our review. ${ }^{26-33}$ Out of these, 3 RCTs were conducted in the indication $\mathrm{AB},{ }^{26-28} 3 \mathrm{RCTs}$ investigated EPs 7630 in children with acute tonsillopharyngitis (ATP), ${ }^{29-31} 1$ open-label clinical trial studied the treatment of aRTI in children and adolescents suffering from preexisting mild asthma, ${ }^{32}$ and 1 RCT investigated the effects of the herbal extract on aRTI in immunocompromised children. ${ }^{33}$

An overview of the clinical trials presented in this review is given in Table 1 .

\section{Results \\ EPs 7630 in treatment of $A B$}

Three RCTs investigating a total of 820 patients aged between 1 and 18 years and suffering from AB were identified. ${ }^{26-28}$ AB symptoms were required to have started less than 48 hours prior to admission. As a further selection criterion, symptom severity was required to equal or exceed 5 points on the Bronchitis Severity Scale (BSS; items "coughing", "pulmonary rales at auscultation", and "dyspnea"). The BSS is a validated clinical tool for the assessment of the severity of $\mathrm{AB}$ on a 5-point scale ranging between 0 "not present" and 4 "very severe". ${ }^{34,35}$ All patients were randomized and treated with EPs 7630 or placebo in a double-blind fashion.

Two of the 3 trials found applied similar protocols, which required double-blind randomization using computer-generated encoding with stratification by age, an enrolment visit at baseline (visit 1), an intermediate follow-up visit on days 3-5 (visit 2), and a final follow-up visit on day 7 (visit 3). ${ }^{26,28}$ The enrolled patients were randomly assigned to treatment with EPs 7630 (age-adjusted dosage: 1 to $<6$ years: $3 \times 10$ drops, 6-12 years: $3 \times 20$ drops, $>12-18$ years: $3 \times 30$ drops) or matched placebo. Overall, there were no significant baseline differences between the two treatment groups, neither in demographic nor in anthropometric terms. In 1 trial, ${ }^{26} 103$ participants received EPs 7630, whereas the placebo group consisted of 97 trial participants. In the other trial, ${ }^{28} 111$ patients received EPs 7630 and 109 placebo.

The change of the BSS total score between baseline and day 7 was defined as primary efficacy outcome. For safety assessment, adverse events (AE; frequency, nature, and severity) as well as vital parameters and laboratory safety parameters were documented at the scheduled visits.

In both trials, the BSS total score reduction was significantly more pronounced under treatment with EPs 7630 as compared to placebo $(p<0.0001$ each, analysis of covariance [ANCOVA]) (Table 1). Also, the severity reduction regarding the individual BSS items "coughing" and "pulmonary rales at auscultation" at day 7 was significantly more pronounced in the EPs 7630 groups than in the respective placebo groups ( $p<0.0001$ in both trials, two-sided $t$-test). In addition, in both trials, a significantly earlier onset of treatment effect was reported in the EPs 7630 group as compared with the placebo 
Table I Randomized controlled trials investigating the efficacy and safety of Pelargonium sidoides extract EPs 7630 in children and adolescents with different manifestations of acute respiratory tract infection

\begin{tabular}{|c|c|c|c|c|c|}
\hline Trial & $\begin{array}{l}\text { Investigation } \\
\text { diagnosis }\end{array}$ & $\begin{array}{l}\text { Primary } \\
\text { outcome } \\
\text { measure }\end{array}$ & Participants & Intervention $^{\mathbf{a}}$ & $\begin{array}{l}\text { Results on primary outcome } \\
\text { measure (mean total score change } \\
\pm \text { SD or } \%)^{b}\end{array}$ \\
\hline $\begin{array}{l}\text { Kamin et al, } \\
2010^{26}\end{array}$ & $A B$ & BSS & $\begin{array}{l}\text { Children and } \\
\text { adolescents aged } \\
\mathrm{I}-18 \text { years }\end{array}$ & $\begin{array}{l}\text { Age-dependent drops EPs } 7630 \\
(n=103) \text { or placebo }(n=97), 7 d\end{array}$ & $\begin{array}{l}\text { Day 7: } 3.4 \pm 1.8(E P s \text { 7630) } 1.2 \pm 1.8 \\
\text { (placebo) }\end{array}$ \\
\hline $\begin{array}{l}\text { Kamin et al, } \\
2010^{27}\end{array}$ & $A B$ & BSS & $\begin{array}{l}\text { Children and } \\
\text { adolescents aged } \\
6-18 \text { years }\end{array}$ & $\begin{array}{l}\text { EPs } 76303 \times 10 \mathrm{mg} / \mathrm{d}(\mathrm{n}=100) \text { or } \\
\text { EPs } 76303 \times 20 \mathrm{mg} / \mathrm{d}(\mathrm{n}=99) \text { or EPs } \\
76303 \times 30 \mathrm{mg} / \mathrm{d}(\mathrm{n}=99) \text { or placebo } \\
(n=101), 7 \mathrm{~d}\end{array}$ & $\begin{array}{l}\text { Day 7: } 3.6 \pm 2.4(\text { EPs } 76303 \times 10 \mathrm{mg} / \mathrm{d}) \\
4.4 \pm 2.4(\mathrm{EPs} 76303 \times 20 \mathrm{mg} / \mathrm{d}) 5.0 \pm 1.9 \\
(E P s 76303 \times 30 \mathrm{mg} / \mathrm{d}) 3.3 \pm 2.6 \text { (placebo) }\end{array}$ \\
\hline $\begin{array}{l}\text { Kamin et al, } \\
2012^{28}\end{array}$ & $A B$ & BSS & $\begin{array}{l}\text { Children and } \\
\text { adolescents aged } \\
\mathrm{I}-18 \text { years }\end{array}$ & $\begin{array}{l}\text { Age-dependent drops EPs } 7630 \\
(n=11 \text { II) or placebo }(n=109), 7 d\end{array}$ & $\begin{array}{l}\text { Day 7: } 4.4 \pm 1.6(E P s ~ 7630) 2.9 \pm 1.4 \\
\text { (placebo) }\end{array}$ \\
\hline $\begin{array}{l}\text { Bereznoy } \\
\text { et al, } 2003^{29}\end{array}$ & ATP & TSS & $\begin{array}{l}\text { Children aged } \\
6-10 \text { years }\end{array}$ & $\begin{array}{l}\text { EPs } 76303 \times 20 \text { drops } / d(n=73) \text { or } \\
\text { placebo }(n=70), 6 d\end{array}$ & $\begin{array}{l}\text { Day 4: 7.I } \pm 2.1 \text { (EPs 7630) } 2.5 \pm 3.6 \\
\text { (placebo) }\end{array}$ \\
\hline $\begin{array}{l}\text { Berezhnoi } \\
\text { et al, } 2016^{30}\end{array}$ & ATP & TSS & $\begin{array}{l}\text { Children aged } \\
6-10 \text { years }\end{array}$ & $\begin{array}{l}\text { EPs } 76303 \times 20 \text { drops } / d(n=60) \text { or } \\
\text { placebo }(n=64), 6 d\end{array}$ & $\begin{array}{l}\text { Day 4c: } 6.7 \pm 2.7 \text { (EPs 7630) } 3.3 \pm 4.2 \\
\text { (placebo) }\end{array}$ \\
\hline $\begin{array}{l}\text { Timen et al, } \\
2015^{31}\end{array}$ & ATP & TSS & $\begin{array}{l}\text { Children aged } \\
6-10 \text { years }\end{array}$ & $\begin{array}{l}\text { Day I-2: up to } 12 \times 20 \text { drops } / d \text { EPs } \\
7630 \\
\text { Day 3-6: } 3 \times 20 \text { drops/d EPs } 7630 \\
(n=40) \text { or placebo }(n=38) 6 d\end{array}$ & $\begin{array}{l}\text { Responder rates day } 4: 90.0 \% \text { (EPs } 7630) \\
44.7 \% \text { (placebo) }\end{array}$ \\
\hline $\begin{array}{l}\text { Tahan and } \\
\text { Yaman, } \\
2013^{32}\end{array}$ & $\begin{array}{l}\text { aRTI with mild } \\
\text { asthma }\end{array}$ & Patient diary & $\begin{array}{l}\text { Children and } \\
\text { adolescents aged } \\
\mathrm{I}-14 \text { years }\end{array}$ & $\begin{array}{l}\text { Age-dependent drops EPs } 7630 \\
\text { plus symptomatic treatment }(n=30) \\
\text { or symptomatic treatment only } \\
(n=31), 5 d\end{array}$ & $\begin{array}{l}\text { Decreased nasal symptoms day 5: } 57 \% \\
\text { (EPs } 7630 \text { plus symptomatic treatment) } \\
26 \% \text { (symptomatic treatment only) } \\
\text { Decreased cough day 5: } 44 \% \text { (EPs } 7630 \\
\text { plus symptomatic treatment) } \\
\text { 10\% (symptomatic treatment only) }\end{array}$ \\
\hline $\begin{array}{l}\text { Patiroglu } \\
\text { et al, } 2012^{33}\end{array}$ & $\begin{array}{l}\text { aRTI with } \\
\text { immune- } \\
\text { deficiency }\end{array}$ & $\begin{array}{l}\text { Parent-filled } \\
\text { questionnaire }\end{array}$ & $\begin{array}{l}\text { Children aged } \\
\mathrm{I}-5 \text { years }\end{array}$ & $\begin{array}{l}\text { EPs } 76303 \times 10 \text { drops } / d(n=14) \text { or } \\
\text { placebo }(n=14), 7 d\end{array}$ & $\begin{array}{l}\text { Without nasal congestion day } 7: 71.4 \% \\
\text { (EPs 7630) } 21.5 \% \text { (placebo) }\end{array}$ \\
\hline
\end{tabular}

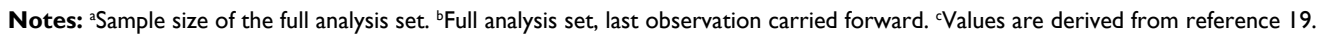

Abbreviations: AB, acute bronchitis; BSS, Bronchitis Severity Scale; ATP, acute tonsillopharyngitis; TSS, tonsillitis-specific symptoms; aRTI, acute respiratory tract infections; d, day(s).

group ( $p<0.0001$ in both trials, two-sided Mantel-Haenszel $\chi^{2}$-test). By day 4 , the onset of treatment effect was reported by $61.1 \%$ (EPs 7630 ) vs $18.5 \%$ (placebo) ${ }^{26}$ and $71.2 \%$ (EPs 7630) vs $33.1 \%$ (placebo), ${ }^{28}$ respectively. Accordingly, data reflecting the evaluation of the treatment by both investigators and patients as assessed by the Integrative Medicine Outcomes Scale (IMOS) resulted in a significant advantage for EPs 7630 over placebo in both trials $(p<0.0001$ in both trials, two-sided Mantel-Haenszel $\chi^{2}$-test). Likewise, the level of satisfaction according to the Integrative Medicine Patient Satisfaction Scale (IMPSS) was better in the EPs 7630 group than the placebo group $(p<0.0001$ in both trials, two-sided Mantel-Haenszel $\chi^{2}$-test). Measuring changes in health-related quality of life, the questionnaire for health state of children (Fragebogen zum Gesundheitszustand für Kinder [FGK]) highlighted an improvement in well-being in both the EPs 7630 and the placebo group, with a significant advantage for the EPs 7630 group for the item "I am feeling ill" in both trials $(p<0.0001$ and $p=0.0485$, respectively, two-sided $t$-test). In the trial published by Kamin et al, ${ }^{26} \mathrm{EPs}$ 7630 significantly exceeded the results of placebo in all items assessed ( $p \leq 0.0002$, two-sided $t$-test).

Between baseline and day 7 , the number of patients on bed rest was reduced markedly in both treatment groups with an advantage for those patients receiving EPs 7630 treatment in both RCTs. Out of those patients who were treated with EPs 7630 , a clearly higher proportion was able to attend work, school, or kindergarten by day 7 than this was the case in the respective placebo groups ( $48.5 \%$ vs $12.4 \%{ }^{27}$ and $57.7 \%$ vs $17.4 \%,{ }^{29}$ respectively).

In both trials, EPs 7630 was well tolerated. There were no intergroup differences found concerning laboratory parameters during the treatment period. AE incidence was only slightly higher in the active treatment groups as compared to placebo with most AEs being reported as gastrointestinal complaints. None of the AEs reported was serious. 
The third RCT identified was a dose-finding study ${ }^{27}$ investigating the efficacy and tolerability of 3 different doses of EPs 7630 in children and adolescents with AB including patients aged between 6 and 18 years. Inclusion criteria were similar to the two above-described RCTs. A total of 400 patients were randomized to treatment with $3 \times 10 \mathrm{mg}$ (101 patients), $3 \times 20 \mathrm{mg}$ (99 patients), or $3 \times 30 \mathrm{mg}$ (99 patients) EPs 7630 or matched placebo (101 patients) daily for 7 days. The full analysis set for efficacy evaluation consisted of 399 trial participants. Primary outcome measure was the validated BSS (items "coughing", "sputum production", "pulmonary rales at auscultation", "chest pain while coughing", and "dyspnea").

Pairwise comparisons of each EPs 7630 group with placebo using the ANCOVA model showed statistically significant differences in the BSS total score reduction at day 7 for the EPs $7630(60 \mathrm{mg})$ and the EPs $7630(90 \mathrm{mg})$ groups ( $p=0.0004$ and $p<0.0001$, respectively, two-sided ANCOVA $p$-values) (Table 1). Regarding the individual BSS items, statistically significant advantages of EPs 7630 were found for the $60 \mathrm{mg}$ and $90 \mathrm{mg}$ groups for the symptoms "coughing" ( $p=0.0433$ and $p=0.0002$, respectively), "sputum production" ( $p=0.0499$ and $p=0.0048$, respectively), and "pulmonary rales at auscultation" $(p=0.0014$ and $p<0.0001$, respectively, two-sided $t$-test, each). Furthermore, a statistically significant advantage with respect to treatment effect onset as reported by the trial participants was found for the EPs $7630(60 \mathrm{mg})$ and EPs $7630(90 \mathrm{mg})$ groups $(p=0.0060$ and $p<0.0001$, respectively, two-sided Mantel-Haenszel $\chi^{2}$-test). Both investigators and patients evaluated the treatment outcome under EPs 7630 significantly better than that achieved under placebo (IMOS). Likewise, patient satisfaction with the treatment as assessed by the IMPSS was also better in the EPs 7630 groups, as were outcomes reflecting the change of health-related quality of life (FGK) between day 0 and day 7. This improvement was more pronounced in the EPs $7630(60 \mathrm{mg})$ and EPs $7630(90 \mathrm{mg})$ groups compared with the placebo group with significant advantages of the EPs $7630(60 \mathrm{mg})$ and EPs $7630(90 \mathrm{mg})$ group over placebo for the FGK item "I am feeling ill" $(p=0.0012$ and $p=0.0001$, respectively, two-sided $t$-test).

The ability to perform daily life activities improved greatest in the EPs $7630(90 \mathrm{mg}$ ) group with $53.5 \%$ of the patients being able to attend work, school, or kindergarten again by day 7. Of those who were administered $60 \mathrm{mg} / \mathrm{d}$ EPs $7630,44.4 \%$ were back to their daily activities by day 7 , whereas patients of the EPs $7630(30 \mathrm{mg})$ and placebo groups achieved nearly comparable results with $35.0 \%$ and $33.7 \%$, respectively.

Safety measures performed in this RCT show that EPs 7630 was well tolerated. Incidence and severity of AEs in all dose groups investigated were low and comparable with those reported in the placebo group. Based on the efficacy and safety results obtained in this dose-finding study, a daily dose of $60 \mathrm{mg}$ EPs 7630 was suggested to be the optimal dose to be applied in children and adolescents with $\mathrm{AB}$.

\section{EPs 7630 in the treatment of acute, non- beta-hemolytic tonsillopharyngitis}

Three RCTs investigating the efficacy and tolerability of EPs 7630 in a total of 346 children aged 6-10 years suffering from ATP were identified.

Two of these trials,,$^{29,30}$ which included $143^{29}$ and $124^{30}$ children, respectively, followed comparable protocols. Children were randomized to a 6-day treatment with either $3 \times 20$ drops/d EPs 7630 or matched placebo, the respective distributions being 73 vs $70^{29}$ and 60 vs $64 .{ }^{30}$ In both RCTs, primary outcome measure was the decrease of tonsillitisspecific symptoms (TSS), which included the items "difficulty in swallowing", "sore throat", "salivation", "redness of the throat", and "fever", measured on a 4-point scale. Fever was classified as $\leq 37.5^{\circ} \mathrm{C}=0 ; 37.5^{\circ} \mathrm{C}$ to $<38.5^{\circ} \mathrm{C}=1$; $38.5^{\circ} \mathrm{C}$ to $<39.5^{\circ} \mathrm{C}=2$; and $>39.5^{\circ} \mathrm{C}=3$. The other symptoms were assessed by the categories "severe" (3), "moderate" (2), "mild" (1), and "not present" (0). Thus, a maximum total score of TSS of 15 points was possible. The change of the TSS total score between baseline and day 4 was evaluated as the primary endpoint.

In both RCTs, the reduction of the TSS total score at day 4 was significantly more pronounced in the active treatment groups as compared to their respective placebo control groups $(p<0.0001$ and $p<0.001$, respectively, ANCOVA) (Table 1). In the trial reported by Bereznoy et al, ${ }^{29}$ a significant difference between the TSS total score reduction rates measured in the EPs 7630 and in the placebo group, respectively, with superiority of the herbal drug extract, was already shown for the first interim visit (day 2). Furthermore, the onset of treatment effect as reported by the members of the active treatment group was significantly superior to placebo already by day $1-2(23 \%$ vs $1.4 \%)$. Accordingly, the proportion of patients who did not need bed rest anymore by day 6 was $87.7 \%$ in the EPs 7630 group and $38.6 \%$ in the placebo group. Data obtained from the second RCT published by Berezhnoi et a ${ }^{30}$ furthermore revealed that the concomitant use of paracetamol 
during the trial was significantly lower in the EPs 7630 group than in the placebo group ( $1.6 \pm 1.5$ vs $2.8 \pm 2.0, p=0.001$, $p$-value of the two-sided Wilcoxon test). These results were confirmed by a recently published meta-analysis of the data ${ }^{19}$ obtained from these two trials. The meta-analysis also showed a significant advantage of EPs 7630 with regard to complete symptom recovery at day 4 .

The third $\mathrm{RCT}^{31}$ included 78 children with nonbetahemolytic ATP. The primary endpoint for assessing the efficacy of EPs 7630 compared to placebo was the proportion of responders (success of therapy) with response being defined by a TSS total score $\leq 4$ points as measured after 4 days of treatment. Trial participants were included upon presentation of a TSS total score of $\geq 6$ points with complaints lasting no longer than 48 hours at treatment start (day 0). TSS ("dysphagia", "sore throat", "salivation", "reddening", "coating left", "coating right", and "fever") were assessed. Local symptoms were assessed by the categories "severe" (3), "moderate" (2), "mild" (1), and "no symptom" (0); values for fever were $\leq 37.5^{\circ} \mathrm{C}=0 ; 37.5^{\circ} \mathrm{C}$ to $<38.5^{\circ} \mathrm{C}=1 ; 38.5^{\circ} \mathrm{C}$ to $<39.5^{\circ} \mathrm{C}=2 ;>39.5^{\circ} \mathrm{C}=3$. Thus, a maximum TSS total score of 21 points was possible. As a dosing regimen, the active treatment group ( 40 children) received 20 drops of EPs 7630 hourly while awake (up to $12 \times 20$ drops/d) on the first 2 days of treatment, and then $3 \times 20$ drops/d on days 3-6. Placebo was administered accordingly in the control group (38 children).

Results showed that the rate of patients with successful therapy was $90.0 \%$ in the EPs 7630 group and $44.7 \%$ in the placebo group, respectively ( $p<0.001$, Fisher's exact test), corresponding to a number needed to treat of 2.21. The difference between the EPs 7630 group and the placebo group with respect to TSS total score was significant as from day 2 onward ( $p<0.001$, Wilcoxon test). Accordingly, concomitant consumption of paracetamol, which was allowed in case of fever $\geq 38.5^{\circ} \mathrm{C}$, was documented for $35.0 \%$ of the EPs 7630 group members and for $47.4 \%$ of the members of the placebo group.

EPs 7630 was well tolerated, even when the administered amount exceeded the daily dosage of $3 \times 20$ drops recommended for children aged 6-12 years. Serious AEs did not occur.

\section{EPs 7630 in the treatment of aRTI in the context of chronic preconditions}

An open monocentric clinical trial ${ }^{32}$ investigated if EPs 7630 could affect the frequency of asthma attacks during viral respiratory tract infection in asthmatic children and adolescents aged 1-14 years. A total of 61 patients suffering from mild asthma (according to the Global Initiative for Asthma 2010 classification) and presenting with viral upper respiratory tract infection were randomly assigned to either EPs 7630 plus symptomatic treatment or symptomatic treatment only. For symptomatic treatment, paracetamol was given. The primary outcome variable was the change in severity and duration of respiratory symptoms; secondary outcome variable was the frequency of asthma attacks. Starting on day 1 and continuing to day 5, patients in the EPs 7630 group were administered $3 \times 10$ drops/d (between 1 and 5 years of age), $3 \times 20$ drops/d (6-12 years), and $3 \times 30$ drops/d (over 12 years), respectively, as well as paracetamol on demand. The second group received only paracetamol on demand. All participants ran patient diaries for documentation of symptom severity over the treatment period. Patient diary entries were evaluated after 5 days of treatment. A blood laboratory test was performed on all patients for eosinophils and immunoglobulin E dosage as well as spirometry and prick test.

Evaluation of the patient diary entries on day 5 showed that treatment with EPs 7630 was associated with a significant reduction in nasal symptoms and frequency of cough $(p<0.05$, $\chi^{2}$-test). Asthma attacks were also significantly reduced in the EPs 7630 group compared to placebo (6 vs 15 attacks) $\left(p<0.05, \chi^{2}\right.$-test) (Table 1$)$. Further studies are needed to confirm these results.

One further $\mathrm{RCT}^{33}$ was designed as a monocentric pilot study and evaluated the efficacy of EPs 7630 in the treatment of symptoms of upper airways infection in children aged between 1 and 5 years suffering from transient hypogammaglobulinemia of infancy (THI). A total of 28 patients with THI who were suffering from aRTI at the time of trial admission were randomized to either EPs 7630 (14 patients) or placebo treatment (14 patients), respectively. Blood laboratory tests were performed before and after the 1-week treatment period. Parents or legal guardians of the trial participants were asked to daily document the development of aRTI symptoms during the treatment period using a 9-item questionnaire to be answered by means of a 2-point scale. Items assessed by the questionnaire were "general state of health", "nasal congestion", "appetite", “daily cough frequency", "nocturnal cough frequency", "fever", "pain”, "sleep pattern”, and "additional symptoms".

In this trial, statistically significant results were seen for EPs 7630 concerning improvement of appetite and nasal congestion.

In both these trials conducted in the context of chronic preconditions, a good tolerability and safety of EPs 7630 could be seen. 


\section{Discussion and conclusion}

Numerous clinical trials have widely shown the efficacy of the P. sidoides preparation EPs 7630 in reducing the symptoms resulting from infection of the airways, from common cold to $\mathrm{AB}$, in the adult population. ${ }^{19,25,36-38}$ The early administration of EPs 7630 has been shown not only to reduce the severity of symptoms but also to prepone the start of symptom improvement, with a reduction of illness duration and an earlier resumption of usual activities in the patients affected.

The trials conducted on pediatric patients that were presented in this review have essentially confirmed the results already observed in the adult population with regard to efficacy and safety of use. These data allow us to make some considerations that are particularly applicable to the pediatric age: pathologies affecting the airways are the reason for frequent requests for medical assessment and substantial drug prescription; the use of antibiotics for this type of pathology is extremely common, especially when there is a persistent high temperature, even if the etiology is typically viral. The early use of EPs 7630 at the onset of signs of respiratory infection reduces or resolves symptoms more rapidly, reduces the risk of bacterial superinfection, ${ }^{15}$ allows more rapid functional recovery, and reduces the use of other drugs such as paracetamol, ${ }^{19}$ or, most importantly, antibiotics, ${ }^{22}$ to counter the increasingly worrying phenomenon of antibiotic resistance. EPs 7630 is well tolerated and can be used in children from the age of 1 year. Furthermore, its use could provide preventive action against clinical worsening or complications, while reducing the need for NSAIDs and antibiotics.

\section{Disclosure}

The authors report no conflicts of interest in this work.

\section{References}

1. van der Walt JJA. Notes on the nomenclature of Pelargonium (Geraniaceae). J South Afr Bot. 1979;45:377-380

2. Moyo M, Van Staden J. Medicinal properties and conservation of Pelargonium sidoides DC. J Ethnopharmacol. 2014;152(2):243-255.

3. M.D., Medicinae Doctor. 2011;18(11):23-29. Italian. Available from: http://www.passonieditore.it/index.html.

4. Hutchings A, Scott AH, Lewis G, Cunningham A. Zulu Medicinal Plants: an Inventory. Pietermaritzburg: University of Natal Press; 1996.

5. Bladt S, Wagner H. From the Zulu medicine to the European phytomedicine Umckaloabo®. Phytomedicine. 2007;14 Suppl 6:2-4.

6. Schoetz K, Erdelmeier C, Germer S, Hauer H. A detailed view on the constituents of EPs ${ }^{\circledR}$ 7630. Planta Med. 2008;74(6):667-674.

7. Kolodziej H. Fascinating metabolic pools of Pelargonium sidoides and Pelargonium reniforme, traditional and phytomedicinal sources of the herbal medicine Umckaloabo®. Phytomedicine. 2007;14 Suppl 6:9-17.
8. Kolodziej H, Kiderlen AF. In vitro evaluation of antibacterial and immunomodulatory activities of Pelargonium reniforme, Pelargonium sidoides and the related herbal drug preparation EPs ${ }^{\circledR} 7630$. Phytomedicine. 2007;14 Suppl 6:18-26.

9. Kolodziej H, Kayser O, Radtke OA, Kiderlen AF, Koch E. Pharmacological profile of extracts of Pelargonium sidoides and their constituents. Phytomedicine. 2003;10 Suppl 4:18-24.

10. Thäle C, Kiderlen A, Kolodziej H. Anti-infective mode of action of EPs ${ }^{\circledR} 7630$ at the molecular level. Planta Med. 2008;74(6):675-681.

11. Thäle C, Kiderlen AF, Kolodziej H. Anti-infective activities of Pelargonium sidoides (EPs $® 7630)$ : effects of induced NO production on Leishmania major in infected macrophages and antiviral effects as assessed in a fibroblast-virus protection assay. Planta Med. 2011;77(7):718-725.

12. Michaelis M, Doerr HW, Cinatl J Jr. Investigation of the influence of EPs ${ }^{\circledR} 7630$, a herbal drug preparation from Pelargonium sidoides, on replication of a broad panel of respiratory viruses. Phytomedicine. 2011;18(5):384-386.

13. Theisen LL, Muller CP. EPs ${ }^{\circledR} 7630$ (Umckaloabo ${ }^{\circledR}$ ), an extract from Pelargonium sidoides roots, exerts anti-influenza virus activity in vitro and in vivo. Antiviral Res. 2012;94(2):147-156.

14. Brown D. Pelargonium sidoides extract (EPs 7630): alternative treatment of acute upper respiratory tract infections. Nat Med J. 2009;1(4):1-6.

15. Conrad A, Jung I, Tioua D, et al. Extract of Pelargonium sidoides (EPs $\mathbb{R}$ 7630 ) inhibits the interactions of group A-streptococci and host epithelia in vitro. Phytomedicine. 2007;14 Suppl 6:52-59.

16. Janecki A, Conrad A, Engels I, Frank U, Kolodziej H. Evaluation of an aqueous-ethanolic extract from Pelargonium sidoides (EPs® 7630) for its activity against group A-streptococci adhesion to human HEp-2 epithelial cells. J Ethnopharmacol. 2011;133(1):147-152.

17. Neugebauer P, Mickenhagen A, Siefer O, Walger M. A new approach to pharmacological effects on ciliary beat frequency in cell cultures - exemplary measurements under Pelargonium sidoides extract (EPs 7630). Phytomedicine. 2005;12(1-2):46-51.

18. Conrad A, Kolodziej H, Schulz V. Pelargonium sidoides-Extrakt (EPs ${ }^{\circledR}$ 7630): Zulassung bestätigt Wirksamkeit und Verträglichkeit [Pelargonium sidoides-extract (EPS $\left.{ }^{\circledR} 7630\right)$ : registration confirms efficacy and safety]. Wien Med Wochenschr. 2007;157(13-14):331-336. German [with English abstract].

19. Matthys H, Lehmacher W, Zimmermann A, Brandes J, Kamin W. EPs 7630 in acute respiratory tract infections - a systematic review and meta-analysis of randomized clinical trials. J Lung Pulm Respir Res. 2016;3(1):00068.

20. Schapowal A, Heger M. EPs ${ }^{\circledR} 7630$ Lösung (Umckaloabo®) bei Sinusitis [EPs $\AA 7630$ solution (Umckaloabo $\AA$ ) in the treatment of sinusitis]. $Z$ Phytother. 2007;28(2):58-65. German [with English abstract].

21. Matthys H, Kamin W, Funk P, Heger M. Pelargonium sidoides preparation (EPs $\left.{ }^{\circledR} 7630\right)$ in the treatment of acute bronchitis in adults and children. Phytomedicine. 2007;14 Suppl 6:69-73.

22. Haidvogl M, Heger M. Treatment effect and safety of EPs ${ }^{\circledR} 7630$-solution in acute bronchitis in childhood: report of a multicentre observational study. Phytomedicine. 2007;14 Suppl 6:60-64.

23. Matthys H, Köhler S, Kamin W. Safety and tolerability of EPs 7630 in clinical trials. Adv Pharmacoepidemiol Drug Saf. 2013;2:4.

24. Llor C. Acute bronchitis: aetiology and treatment. Eur Respir Monogr. 2013;60:1-17.

25. Timmer A, Günther J, Motschall E, Rücker G, Antes G, Kern WV. Pelargonium sidoides extract for treating acute respiratory tract infections. Cochrane Database Syst Rev. 2013;(10):CD006323.

26. Kamin W, Maydannik V, Malek FA, Kieser M. Efficacy and tolerability of EPs 7630 in children and adolescents with acute bronchitis - a randomized, double-blind, placebo-controlled multicenter trial with a herbal drug preparation from Pelargonium sidoides roots. Int $J$ Clin Pharmacol Ther. 2010;48(3):184-191.

27. Kamin W, Maydannik VG, Malek FA, Kieser M. Efficacy and tolerability of EPs 7630 in patients (aged 6-18 years old) with acute bronchitis: a randomized, double-blind, placebo-controlled clinical dose-finding study. Acta Paediatr. 2010;99(4):537-543. 
28. Kamin W, Ilyenko LI, Malek FA, Kieser M. Treatment of acute bronchitis with EPs 7630: randomized, controlled trial in children and adolescents. Pediatr Int. 2012;54(2):219-226.

29. Bereznoy VV, Riley DS, Wassmer G, Heger M. Efficacy of extract of Pelargonium sidoides in children with acute non-group A beta-hemolytic streptococcus tonsillopharyngitis: a randomized, double-blind, placebocontrolled trial. Altern Ther Health Med. 2003;9(5):68-79.

30. Berezhnoi VV, Heger M, Lehmacher W, Seifert G. Clinical efficacy and safety of liquid Pelargonium sidoides preparation (EPs 7630) in children with acute non-streptococcal tonsillopharyngitis. J Compr Ped. 2016;7(4):e42158.

31. Timen G, Zabolotnyi D, Heger M, Lehmacher W. EPs 7630 is effective in children with acute, non- $\beta$ haemolytic streptococcal tonsillopharyngitis - results of a double-blind, placebo-controlled, multicentre trial. Malays J Paediatr Child Health. 2015;21:36-50.

32. Tahan F, Yaman M. Can the Pelargonium sidoides root extract EPs ${ }^{\circledR}$ 7630 prevent asthma attacks during viral infections of the upper respiratory tract in children? Phytomedicine. 2013;20(2):148-150.
33. Patiroglu T, Tunc A, Eke Gungor H, Unal E. The efficacy of Pelargonium sidoides in the treatment of upper respiratory tract infections in children with transient hypogammaglobulinemia of infancy. Phytomedicine. 2012;19(11):958-961.

34. Kardos P, Lehrl S, Kamin W, Matthys H. Assessment of the effect of pharmacotherapy in common cold/acute bronchitis - the Bronchitis Severity Scale (BSS). Pneumologie. 2014;68(8):542-546.

35. Lehrl S, Matthys H, Kamin W, Kardos P. The BSS - a valid clinical instrument to measure the severity of acute bronchitis. J Lung Pulm Respir Res. 2014;1(3):00016.

36. Lizogub VG, Riley DS, Heger M. Efficacy of a Pelargonium sidoides preparation in patients with the common cold: a randomized, doubleblind, placebo-controlled clinical trial. Explore (NY). 2007;3(6):573-584.

37. Agbabiaka TB, Guo R, Ernst E. Pelargonium sidoides for acute bronchitis: a systematic review and meta-analysis. Phytomedicine. 2008;15(5):378-385.

38. Agbabiaka TB, Guo R, Ernst E. Pelargonium sidoides for acute bronchitis: a systematic review and meta-analysis [Erratum]. Phytomedicine. 2009;16(8):798-799.
International Journal of General Medicine

\section{Publish your work in this journal}

The International Journal of General Medicine is an international, peer-reviewed open-access journal that focuses on general and internal medicine, pathogenesis, epidemiology, diagnosis, monitoring and treatment protocols. The journal is characterized by the rapid reporting of reviews, original research and clinical studies across all disease areas.

\section{Dovepress}

The manuscript management system is completely online and includes a very quick and fair peer-review system, which is all easy to use. Visit http://www.dovepress.com/testimonials.php to read real quotes from published authors.

Submit your manuscript here: https://www.dovepress.com/international-journal-of-general-medicine-journal 